\title{
Nonnative, Noninvasive Woody Species Can Enhance Urban Landscape Biodiversity
}

\author{
Linda Chalker-Scott
}

\begin{abstract}
Increasingly, homeowner associations and municipalities are requiring a certain percentage of native trees and shrubs as part of any new landscape installation. These native species mandates make numerous claims as to the superiority of native plants over introduced species, including their ability to enhance ecosystem biodiversity. In contrast, nonnative trees and shrubs are labeled as harmful to biodiversity, primarily because they are improperly grouped with known invasive species. This review summarizes the current published science regarding the effects of native and nonnative woody species on urban landscape stability as measured by biodiversity of associated plants, birds, insects, reptiles, and mammals. The preponderance of studies demonstrate that parameters other than species nativity have the greatest influence on biodiversity of these groups. Rather than limiting tree and shrub selection lists to a narrow palette of native species, a more practical, science-based approach to enhancing urban landscape biodiversity is suggested.

Key Words. Alien Species; Biodiversity; Botanical Gardens; Golf Courses; Home Gardens; Native Species; Nonnative Species; Planting Mandates; Public Parks; Residential Landscapes.
\end{abstract}

Native plant species are increasingly popular choices for urban gardens and landscapes, as evidenced by the proliferation of native plant societies, native plant nurseries, and most recently native plant mandates-legally enforceable policies. Early native species mandates were found primarily in highway revegetation efforts (U.S. Department of Transportation ND), where previous plantings of invasive species became management problems. Emerging requirements for ecological restoration of wetlands and natural areas have also heightened public awareness of how important native species can be in creating a functional ecosystem. In contrast, introduced ornamental species can be perceived as undesirable, hazardous, or unsustainable [in spite of "their ubiquitous presence in most towns and cities" (Hitchmough 2011)].

There is widespread belief that native plants are superior to introduced species because of their adaptation to local environmental conditions. This belief is bolstered by governmental organizations, including the U.S. Environmental Protection Agency (EPA) and National Park Service (NPS), which make many scientifically unsup- ported statements about native plant superiority on their websites (NPS 2005; EPA 2012). These native species attributes fall into two categories that are actually independent of species nativity:

Plant functionality:

- help reduce air pollution (EPA)

- produce long root systems to hold soil in place (NPS)

- promote biodiversity (EPA)

- protect water quality by controlling soil erosion and moderating floods and droughts (NPS)

- provide shelter and food for wildlife (EPA, NPS)

Plant selection and management:

- do not require fertilizers (EPA, NPS)

- help slow down the spread of fire by staying greener longer (NPS)

- require fewer pesticides (EPA)

- require less water (EPA, NPS)

- require very little long-term maintenance 
if they are properly planted and established (NPS)

- $\quad$ save money (EPA)

Despite the lack of evidence to support these assertions (Kendle and Rose 2000; Davis et al. 2011), native plant superiority continues to be promoted and entrenched into policy as community planting mandates (Ingram 1999; Smith 2013) and sometimes to justify nonnative tree removal (Engardio 2013). Mandates include "native only" policies, such as those adopted by the Village of Riverside, Illinois, U.S. (2010), as well as policies requiring a certain percentage of natives in new tree plantings (New York City Council 2010). In this latter policy, the Council states that "native plants provide habitats for local birds, insects, and other animals that are indigenous to our region"-even though this urban environment surely bears little resemblance to the ecosystem that existed prior to development.

Thus, the increased interest in native plant and animal species is entwined with a heightened awareness of their sometimes tenuous existence in urban areas. Long-term studies have documented the loss of native species in urbanized landscapes. Though this decrease in biodiversity is largely driven by land-use changes, such as the transformation from rural to urban land use and the historic drainage of wetlands (Knapp et al. 2010), there is a perception that biodiversity loss is due to nonnative species forcing native species into extinction. In preamble to its biodiversity law for public landscapes, the New York City Council (2010) states that "nonnative species often out-compete native plant species leaving native species and the animals that depend on them vulnerable to depletion or even extinction."

This perception is augmented by a related corollary-that only native plants can fill ecological roles in landscapes (Lukas 2011). For instance, Tallamy and Shropshire (2009) claim that insects prefer native to nonnative species. The authors correctly point out that productive landscapes are critical to supporting terrestrial food webs and that plant genera with no local species harbor fewer lepidopteran species than plant genera with local species representation. However, the authors label entire plant genera as "native" or "alien" based solely on whether the genus contains species native to the northeastern U.S. In doing so, nearly 200 introduced woody species are folded into "native" genera, some of which (e.g., Berberis, Lonicera, Prunus, Rosa, and Rubus) contain aggressively invasive, nonnative species, which are spread by members of that food web. Extrapolating the results of this study to determine the effect of invasive species on biodiversity is not possible, as those species were combined with natives at the genus level.

\section{METHODOLOGY}

The purpose of this review is to answer the question: Do native and nonnative woody species differ in how they affect species diversity? To address this question, the author considered information drawn from a global survey of relevant, peer-reviewed, scientific articles found across several databases (AGRICOLA, BIOSIS, CABI, and ISI Web of Science) from 1990 to 2014. Both native and nonnative (or the synonymic terms alien, introduced, and invasive) were required search terms. While there is no scientific consensus on the exact definitions of these terms (Sagoff 2005), they served to identify relevant papers. Ecological restoration research was excluded from consideration, as native species are required for installation. Likewise, the author did not include publications on geographically isolated and/or exceptionally sensitive areas, such as Hawai'i, U.S., where even noninvasive introduced species can have significant disruptive effects on native ecosystems (Lukas 2011). Thus, interpreting the findings of this paper in the context of such sensitive places should be done with caution.

Native planting mandates can require removal of nonnative trees and shrubs, which are often well-established components of landscapes and whose removal can be disruptive to that landscape's function. Therefore, a second set of search terms, which define the author's species of interest, were included-trees and shrubs. Both terms were included as the line between large shrubs and small trees is blurry. The search was limited to research focused on woody plants, not ground covers, lawns, or flowering annuals and herbaceous perennials.

The third set of search terms focused on urban landscapes. The author defined urban landscapes to include settings such as public parks, golf courses, remnant natural areas, botanical gardens, private residences, and traffic roundabouts. Scientific articles that met the "urban landscape" definition also needed to include measures of biodiversity apart 
from the tree species themselves. In other words, the articles had to consider the impact of native or nonnative woody species on the biodiversity of birds, insects, mammals, reptiles, or other plants. Thus, the fourth search term was biodiversity (which encompasses the earlier ecological terms species richness, species evenness, and species diversity).

The final review collection represented more than 120 articles from 30 countries on every landscaped continent (Table 1).

Table 1. Study sites represented in the literature review.

\begin{tabular}{|c|c|}
\hline Continental area & Countries \\
\hline North America & $\begin{array}{l}\text { Canada ( } 3 \text { provinces) } \\
\text { United States (11 states) }\end{array}$ \\
\hline Central America & $\begin{array}{l}\text { Mexico } \\
\text { Puerto Rico }\end{array}$ \\
\hline South America & $\begin{array}{l}\text { Argentina } \\
\text { Brazil } \\
\text { Chile } \\
\text { Peru } \\
\text { Uruguay }\end{array}$ \\
\hline Europe & $\begin{array}{l}\text { Bulgaria } \\
\text { Czech Republic } \\
\text { Denmark } \\
\text { France } \\
\text { Germany } \\
\text { Slovakia } \\
\text { Spain } \\
\text { Switzerland } \\
\text { Turkey } \\
\text { United Kingdom }\end{array}$ \\
\hline Asia & $\begin{array}{l}\text { China } \\
\text { India } \\
\text { Japan } \\
\text { Malaysia } \\
\text { Nepal } \\
\text { Philippines } \\
\text { Taiwan }\end{array}$ \\
\hline Middle East & Israel \\
\hline Africa & South Africa \\
\hline Oceania & $\begin{array}{l}\text { Australia } \\
\text { New Zealand }\end{array}$ \\
\hline
\end{tabular}

\section{INFLUENCE OF TREE PROVENANCE ON LANDSCAPE BIODIVERSITY- A REVIEW OF THE LITERATURE}

\section{Plants}

Relatively few studies have investigated the influence of tree provenance on affiliated native plant species. One group of plants that can be depen- dent on native tree species are epiphytic species. Some orchids (Adhikari et al. 2012a) and lichens (Eliasaro et al. 2009), for instance, have specific host preferences. All epiphytes, however, benefit from the presence of older trees, which provide thick, coarse bark for attachment (Adhikari et al. 2012b).

For all other plant groups, however, the presence of nonnative species was not detrimental to native plant species richness. Of particular importance were edge habitats-those transitional areas between different landscape types. Even though edge habitats often contain nonnative species, these edges were richer in both total native species and native forest specialists than forest interiors (Vallet et al. 2010), which presumably would have fewer nonnative species. Such edges may play a role as refuges for remnant populations of rare and endangered plants (Roberts et al. 2007). Home gardens and other cultivated areas may also serve as conservation refuges for endangered and vulnerable plant species (Roberts et al. 2007; Akinnifesi et al. 2010; Pozi et al. 2013; Schmidt et al. 2014).

\section{Birds}

Bird activity is easily monitored, and many researchers have investigated the relationship between native birds and tree species in urban landscapes. Urbanization and the inevitable introduction of nonnative plant species favors omnivorous, carnivorous, frugivorous, granivorous, nectarivorous, and cavity-nesting species, but can threaten those that nest or forage in grasses or on the ground (Miller et al. 2003; la Sorte and Boecklen 2005; Leveau and Leveau 2005; Chace and Walsh 2006; Davis et al. 2012).

The most noticeable effects of urbanization on bird species diversity occur when open pasture and grassland habitats are converted to shrub or treedominated communities (Standley 2003). Many native birds are ground nesters, and their numbers plummet as native grasses and forbs are replaced by lawns, shrubs, and trees (Marzluff and Ewing 2001; Miller et al. 2003; Shwartz et al. 2008; Hudson and Bird 2009). Yet even these urban areas have a high bird richness and density due to the shift in bird community structure, as grassland species are replaced by native forest species better adapted to urbanized landscapes (Miller et al. 2003; Leveau and Leveau 2005; MacGregor-Fors 2008; Khera et al. 2009). 
Surprisingly, native bird numbers and species richness can increase with the development status of land, perhaps correlating to the diversity of trees and shrubs planted. Suburban, residential areas have greater numbers of birds (Sewell and Catterall 1998; Shwartz et al. 2008; Catterall et al. 2010) and bird species (Sewell and Catterall 1998; Reis et al. 2012; Taylor et al. 2013) compared to other systems, including remnant forests (Sewell and Catterall 1998), rural areas (Leveau and Leveau 2005), and other unmanaged systems (Shwartz et al. 2008). While forests tend to provide mainly seed as a food source, urban gardens provide a wide range of resources, including fruit, nectar, and pollen (Smith et al. 2006; van Heezik et al. 2013). Moreover, an urbanized landscape provides resources throughout the year, which is of particular benefit to native birds during the winter (Atchison and Rodewald 2006).

Large trees and large habitats are important to native bird species. In environments that vary from Northern California to tropical Mexico to the Canary Islands, bird species richness is positively related to tree height (Palomino and Carrascal 2005; MacGregor-Fors 2008; Kalinowski et al. 2010; Strubbe et al. 2010; Stagoll et al. 2012). Likewise, native bird species richness increases with increased habitat size, particularly that of insectivores, hollownesters, and other forest species (Donnelly and Marzluff 2004; Donnelly and Marzluff 2006; Posa and Sodhi 2006; Lu et al. 2007; Hudson and Bird 2009; Khera et al. 2009; Strubbe et al. 2010; Ikin et al. 2013a; van Heezik et al. 2013; Yu and Guo 2013).

Tree provenance appears to influence bird populations more than other animal groups, with several papers associating greater species richness with native tree density (Pennington et al. 2008; Helden et al. 2012; Petrova and Irikov 2012; Reis et al. 2012; Ikin et al. 2013b). This may be more a failure to retain appropriate habitat composition rather than native plant species, however, as an ecologically functional environment is required for improving native bird diversity (Parsons et al. 2004) and may be more important than provenance. Birds, including native forest species, prefer urban sites that retain vegetative characteristics such as structure (Chace and Walsh 2006; Hodgkison et al. 2007; van Heezik et al. 2008; Khera et al. 2009; Echevarria et al. 2011) and density (Hennings and Edge 2003; Chen et al. 2005; Donnelly and Marzluff 2006; Faggi and Perepelizin
2006; Posa and Sodhi 2006; Lu et al. 2007; Luther et al. 2008; MacGregor-Fors 2008; Pennington et al. 2008; van Heezik et al. 2008; Kalinowski et al. 2010; de Toledo et al.2012), which could be supplied either by native or carefully selected introduced species.

While some native birds are undoubtedly dependent on native tree species, others have learned to utilize introduced trees, including invasives, for food [e.g., holly berries (Ilex spp.), figs (Ficus spp.), and honeysuckle (Lonicera spp.) nectar] and habitat for nesting and predator avoidance (e.g., Cytisus scoparius) (Sewell and Catterall 1998; Crooks et al. 2004; Feldman and Krannitz 2004; Hasebe and Franklin 2004; Leveau and Leveau 2005; Atchison and Rodewald 2006; Kath et al. 2009; Gleditsch and Carlo 2011; Caughlin et al. 2012; Helden et al. 2012; Moller et al. 2012). The relationship between native birds, especially frugivorous species, and introduced plants is complex. Not only do many invasive trees and shrubs expand habitat choices for native birds, but these birds contribute to invasive plant spread through fruit consumption and seed dispersal (Reichard et al. 2001; Caughlin et al. 2012; Moller et al. 2012).

In summary, native bird species abundance and richness are positively influenced by:

- habitat connectivity and size (Donnelly and Marzluff 2004; Donnelly and Marzluff 2006; Posa and Sodhi 2006; Hudson and Bird 2009; Khera et al. 2009; Strubbe et al. 2010; van Heezik et al. 2013; Yu and Guo 2013)

- abundance and diversity of trees and shrubs (Sewell and Catterall 1998; Hennings and Edge 2003; Crooks et al. 2004; Chen et al. 2005; Palomino and Carrascal 2005; Donnelly and Marzluff 2006; Faggi and Perepelizin 2006; Posa and Sodhi 2006; Hodgkison et al. 2007; Lu et al. 2007; Luther et al. 2008; MacGregor-Fors 2008; Pennington et al. 2008; Shwartz et al. 2008; van Heezik et al. 2008; Hudson and Bird 2009; Kath et al. 2009; Khera et al. 2009; Suarez-Rubio and Thomlinson 2009; Kalinowski et al. 2010; Ortega-Alvarez and MacGregor-Fors 2010; de Toledo et al. 2012)

- vertical diversity (Hodgkison et al. 2007; van Heezik et al. 2008; Khera et al. 2009)

- moderately disturbed sites, such as suburbs and public greenspaces (Blair 1996; Crooks et 
al. 2004; Feldman and Krannitz 2004; Hasebe and Franklin 2004; Leveau and Leveau 2005; Atchison and Rodewald 2006; Faggi and Perepelizin 2006; Shwartz et al. 2008; Catterall et al. 2010; Ikin et al. 2013a; Taylor et al. 2013)

- native vegetation for specialist species (Chace and Walsh 2006; Hodgkison et al. 2007; Pennington et al. 2008; van Heezik et al. 2008; Petrova and Irikov 2012; Reis et al. 2012; Ikin et al. 2013b)

- older, larger trees (Palomino and Carrascal 2005; MacGregor-Fors 2008; Ortega-Alvarez and MacGregor-Fors 2010; Strubbe et al. 2010; Stagoll et al. 2012)

- hollow trees for nesting (Ikin et al. 2013a)

- herbaceous/grass cover (Feldman and Krannitz 2004; Chen et al. 2005)

- permanent water source (Shwartz et al. 2008)

\section{Insects}

In contrast to Tallamy and Shropshire's research (2009) referenced earlier, the majority of papers reviewed for this study found no support for the assertion that native insect diversity is harmed by introduced tree species. Hanley et al. (2014) state that "gardeners can encourage pollinators without consideration of plant origin or bias towards 'local' biogeographical species." Urban areas, which include mixtures of native and nonnative species, can provide habitat for native insects and increase overall species diversity (Whitmore et al. 2002; Delabie et al. 2007; Ferracini and Alma 2007; Hodge et al. 2010; Sattler et al. 2011; Wray et al. 2014). In fact, even invasive trees were found to meet and diversify insect habitat needs (Blanchon et al. 2011), particularly as native host trees have disappeared (Raju 2003; Fetridge et al. 2008). There is a rich diversity of insects, especially pollinators, such as bees and butterflies, supported in community, botanical, and residential gardens, all of which routinely include introduced plant species (Raju 2003; Yates et al. 2005; Fetridge et al. 2008; Frankie et al. 2009; Pryke and Samways 2009).

Overall, insect species abundance and richness are positively influenced by the following vegetation factors:

- habitat connectivity (Brown Júnior and Freitas 2002)
- abundance and diversity of trees and shrubs (McIntyre and Hostetler 2001; Whitmore et al. 2002; Delabie et al. 2007; Pryke and Samways 2009; Hodge et al. 2010; Uno et al. 2010; Pecarevic et al. 2010)

- profusely flowering species with seasonal diversity (Raju 2003; Tommasi et al. 2004; Yates et al. 2005; Frankie et al. 2009)

- large trees (Borges Júnior et al. 2011)

- hollow trees for nesting (Antunes et al. 2012)

- permanent water source (Brown Júnior and Freitas 2002)

Recalling the popular belief that native plant species require fewer pesticides, the author looked for supporting evidence in the collected literature. In some cases, there was simply no difference between pest insect presence on native and nonnative trees (Kulfan et al. 2010; Ryall 2010), while others reported less damage to exotic species (Matter et al. 2012). In other studies, native trees in forest settings were damaged more by chewing insects than those in urban or ornamental plantings (Nuckols and Connor 1995; Guthrie et al. 2008). Finally, the havoc wreaked upon native tree species by the introduced emerald ash borer (Agrilus planipennis), Dutch elm disease (Ophiostoma spp.), and sudden oak death (Phytophthora ramorum) is definitive evidence that nativeness does not confer resistance to pests.

\section{Mammals}

While one paper identified native vegetation on golf courses as one of several criteria needed to enhance native mammal diversity (Hodgkison et al. 2007), the remainder of the papers surveyed cited other factors as more critical. Urban environments, with their collections of native and nonnative trees, support a broad variety of mammals, especially those that depend on the habitat structure and resources trees provide (Caldara Jr. and Leite 2007; Bonnington et al. 2014). While parking strips and other fragmented greenspaces aren't large enough to support some mammals (Fernández and Simonetti 2013), suburbs with large acreage serve to protect threatened species, such as bandicoots (Daniels and Kirkpatrick 2012), fox squirrels (Jodice and Humphrey 1992), and bats (Basham et al. 2011) even better than wildlands. 
Generally, mammal abundance and richness are positively influenced by the following vegetation factors:

- habitat size (Oprea et al. 2009; Basham et al. 2011; Daniels and Kirkpatrick 2012)

- vertical structure (Garden et al. 2007; Andrade-Núñez and Aide 2010; Garden et al. 2010)

- tree density (canopy cover) (Andrade-Núñez and Aide 2010)

- tree species diversity (Jodice and Humphrey 1992; Andrade-Núñez and Aide 2010; Brearley et al. 2011)

- large trees and hollow trees (Basham et al. 2011; Brearley et al. 2011)

- grass cover between forests and other habitats (Hodgkison et al. 2007; Andrade-Núñez and Aide 2010; Brearley et al. 2011)

- permanent water source (Daniels and Kirkpatrick 2012)

These papers provide solid evidence that introduced tree species, including invasives, can meet and enhance habitat needs for native mammal populations.

\section{Reptiles}

Most research on native reptile diversity and tree provenance has been conducted in Australia. There, researchers have linked richness and diversity of skinks and other reptiles to a structurally complex, species-rich assemblage of trees and shrubs (Garden et al. 2007; Hodgkison et al. 2007; Garden et al. 2010; Brown et al. 2011), some of which correlated directly to prey availability (Garden et al. 2007). Specific site variables identified as beneficial to reptile diversity were:

- tree density and size (Brown et al. 2011)

- hollow trees and woody debris (Garden et al. 2007; Brown et al. 2011)

- herbaceous cover (Garden et al. 2007; Hodgkison et al. 2007)

\section{THE RATIONALE REVISITED}

As native-only policies and mandates expand in countries such as the USA and UK, so does research on the validity of the topic (Kendle and Rose 2000; Johnston et al. 2012). Far from damaging native spe- cies biodiversity, introduced trees and shrubs have documented benefits for plant and animal species abundance and richness. Thus, the science does not support the supposition that native plantings are required for enhancing community diversity. Summarizing their review of native species mandates, Johnson et al. (2012) declare "it is clear that any automatic preference for native trees when planting in urban areas is not a science-based policy." There are a number of related misconceptions that contribute to this erroneous belief that are worth addressing, especially as they relate to policy making:

- The definitions of native and alien species are value judgments, not science-based concepts. As Kendle and Rose (2000) state so clearly, nativeness is "not founded on hard science, as often implied, but reflects a set of value judgments about the timescales of environmental change and forms of human impact regarded as acceptable within the landscape."

- Native species are often poorly suited to urban conditions. Many native environments were forest ecosystems; after urban development they rarely resemble a natural habitat. Trees and shrubs adapted to shaded, moist conditions do not thrive in sunny sites with bare, compacted soil. The less urban soils resemble the original soil types, the less native plant species will be likely to tolerate them. Furthermore, climate change is occurring at a rate that makes it difficult for many native species to adapt.

- Introduced species provide ecological benefits. As this literature review demonstrates, nonnative species can and do play important roles in creating habitat for native plant and animal species. Even aggressive and invasive shrub species, such ascotoneaster (Cotoneaster spp.) and blackberry (Rubus discolor), along with a number of herbaceous weedy species, can be the most popular resources for native pollinators (Tommasi et al. 2004). Wholesale removal of invasive species can have the unintended effect of depauperating native bee populations. Furthermore, stands of older, introduced trees have demonstrated value in carbon storage (Freedman et al. 1996) no different from that of native trees (O'Donoghue and Shackleton 2013). 
- Not all introduced species are invasive. In fact, a 1997 study found that less than 10\% of the more than 4,000 introduced plant species found outside of cultivation in the U.S. truly met the standard of invasiveness (Reichard and Hamilton 1997). A more recent, smallscale analysis of the Machu Picchu Sanctuary in Peru determined that while a similar percentage of the introduced plant species were invasive, the great majority "apparently do not represent an actual threat to local biodiversity" (Ochoa and Andrade 2003).

- Many introduced species are better adapted than native plants for urban environments. From air pollution to zinc contamination, urban landscapes provide a litany of environmental challenges to plant communities. Urban areas are typically brighter, hotter, and drier than surrounding forest systems, and the trees that thrive in these conditions are often nonnatives (Chocholoušková and Pyšek 2003). The fact that introduced species make up a substantial proportion of these urban plant communities globally, sometimes to the point of becoming naturalized or invasive, is evidence that native plants are not necessarily the best-adapted species in what is essentially a human environment-not a native ecosystem.

\section{MANAGING URBAN LANDSCAPES FOR OPTIMAL BIODIVERSITY}

The published research overwhelmingly identifies diversity, structure, and function as the most important vegetation characteristics for enhancing community biodiversity (Garden et al. 2007; Nielsen et al. 2014). Native species are part of this scenario, but they do not have to be the primary contributor to community biodiversity. In fact, sometimes landscapes require the inclusion of exotic trees and control of natives to maintain biodiversity (Kirkpatrick 2004). Sagoff (2005) goes as far to say that "introduced organisms typically, generally, and significantly add to species richness in ecosystems."

There are specific actions, supported by published research, landscape managers can take to maintain or enhance species biodiversity in urban greenspaces. Table 2 summarizes general site and vegetation traits that are positively associated with animal species abundance and richness. Table 3 describes tree selection criteria that can be used to enhance ecosystem biodiversity by the judicious use of native and noninvasive, introduced species. Reichard and Hamilton (1997) have developed a simple, practical decision tree that can aid landscape managers in selecting tree and shrub species least likely to become invasive. Table 4 presents practical steps that can be taken to meet specific management goals in selecting and maintaining tree and shrub species for optimal community biodiversity.

Table 2. Site and vegetation traits associated with animal species abundance and richness ${ }^{2}$.

\begin{tabular}{|c|c|c|c|c|}
\hline Vegetation trait & Birds & Insects & Mammals & Reptiles \\
\hline $\begin{array}{l}\text { Habitat structure (canopy cover, vertical } \\
\text { diversity, tree and shrub density and diversity) }\end{array}$ & $\mathrm{X}$ & $\mathrm{X}$ & $\mathrm{X}$ & $\mathrm{X}$ \\
\hline Larger and/or connected sites & $\mathrm{X}$ & $\mathrm{X}$ & $\mathrm{X}$ & \\
\hline Older, larger trees & $\mathrm{X}$ & $\mathrm{X}$ & $\mathrm{X}$ & $\mathrm{X}$ \\
\hline Hollow trees & $\mathrm{X}$ & $\mathrm{X}$ & $\mathrm{X}$ & $\mathrm{X}$ \\
\hline Woody debris & & & & $\mathrm{X}$ \\
\hline Moderately disturbed sites & $\mathrm{X}$ & & & \\
\hline $\begin{array}{l}\text { Profusely flowering species with } \\
\text { seasonal diversity }\end{array}$ & & $\mathrm{X}$ & & \\
\hline Native vegetation ${ }^{y}$ & $\mathrm{X}$ & $\mathrm{X}$ & & \\
\hline Herbaceous/grass cover & $\mathrm{X}$ & & $\mathrm{X}$ & $\mathrm{X}$ \\
\hline Permanent water source & $\mathrm{X}$ & $\mathrm{X}$ & $\mathrm{X}$ & \\
\hline
\end{tabular}


Table 3. Selecting tree and shrub species to enhance ecosystem biodiversity.

\begin{tabular}{|c|c|c|c|}
\hline Goal & Activity & Information to collect & References \\
\hline $\begin{array}{l}\text { Determine the need } \\
\text { for new trees }\end{array}$ & Conduct tree surveys & $\begin{array}{l}\text { Age distribution, canopy cover, percent } \\
\text { natives, species diversity }\end{array}$ & \\
\hline $\begin{array}{l}\text { Determine potential } \\
\text { environmental stresses }\end{array}$ & Evaluate site conditions & $\begin{array}{l}\text { Air pollution, drought, heat, light, salt, } \\
\text { soil conditions, pests, disease }\end{array}$ & $\begin{array}{l}\text { Pair 1994; } \\
\text { Kirnbauer et al. } 2009\end{array}$ \\
\hline $\begin{array}{l}\text { Determine community } \\
\text { needs for specific } \\
\text { resources }\end{array}$ & Diversify plant palette & $\begin{array}{l}\text { Food, nesting habitat needs for native } \\
\text { species of interest }\end{array}$ & \\
\hline $\begin{array}{l}\text { Determine potential } \\
\text { invasiveness }\end{array}$ & $\begin{array}{l}\text { Research possible introductions } \\
\text { using decision tree }\end{array}$ & $\begin{array}{l}\text { Any relevant plant introduction regulations; } \\
\text { data on invasiveness of related species }\end{array}$ & $\begin{array}{l}\text { Reichard and } \\
\text { Hamilton 1997; } \\
\text { Kirnbauer et al. 2009; } \\
\text { Zhu et al. } 2010\end{array}$ \\
\hline
\end{tabular}

Table 4. Managing urban greenspaces to enhance native community biodiversity.

\begin{tabular}{|c|c|c|}
\hline Goal & Activity & References \\
\hline $\begin{array}{l}\text { Reduce invasive } \\
\text { plant species }\end{array}$ & $\begin{array}{l}\text { * Plant alternative resources before removing invasives with food or nesting value } \\
\text { * Remove invasives favored for nesting during the winter } \\
\text { * Remove invasives favored for food only when ample alternatives present }\end{array}$ & $\begin{array}{l}\text { Eliasaro et al. 2009; Kath et al. } \\
\text { 2009; Gleditsch and Carlo 2011; } \\
\text { Adhikari et al. 2012a; }\end{array}$ \\
\hline $\begin{array}{l}\text { Increase tree and } \\
\text { shrub species } \\
\text { diversity }\end{array}$ & * Plant native as well as non-invasive introduced species & Santamour 1978 \\
\hline $\begin{array}{l}\text { Maintain a vertically } \\
\text { diverse assemblage } \\
\text { of vegetation }\end{array}$ & $\begin{array}{l}\text { * Plant more ground and shrub vegetation for bird habitat } \\
{ }^{*} \text { Plant trees in groups rather than as isolates } \\
{ }^{*} \text { Retain deadwood and other nesting structures in place when possible }\end{array}$ & $\begin{array}{l}\text { Oneal and Rotenberry } 2008 \text {; } \\
\text { Suarez-Rubio and Thomlinson } \\
\text { 2009; Adhikari et al. } 2012 \text { b }\end{array}$ \\
\hline $\begin{array}{l}\text { Improve tree size } \\
\text { distribution }\end{array}$ & $\begin{array}{l}{ }^{*} \text { Protect middle-aged trees to ensure longevity } \\
{ }^{*} \text { Retain old, large trees } \\
{ }^{*} \text { Use small "urban" tree species sparingly }\end{array}$ & $\begin{array}{l}\text { Marzluff and Ewing 2001; } \\
\text { Landmann 2006; Nagendra and } \\
\text { Gopal 2011; Adhikari et al. 2012b }\end{array}$ \\
\hline $\begin{array}{l}\text { Enhance ecosystem } \\
\text { edges }\end{array}$ & $\begin{array}{l}{ }^{*} \text { Increase diversity of plants in edge habitats } \\
{ }^{*} \text { Reduce management of edges (e.g., no mowing, pesticide application, etc.) }\end{array}$ & $\begin{array}{l}\text { Marzluff and Ewing 2001; Stewart } \\
\text { et al. 2004; Roberts et al. 2007; } \\
\text { Shwartz et al. 2008; Vallet et al. } \\
2010\end{array}$ \\
\hline $\begin{array}{l}\text { Reduce predation } \\
\text { on native animal } \\
\text { species }\end{array}$ & ${ }^{*}$ Reduce managed, open lawns & Marzluff and Ewing 2001 \\
\hline $\begin{array}{l}\text { Improve soil habitat } \\
\text { for insects, reptiles, } \\
\text { and mammals }\end{array}$ & ${ }^{*}$ Reduce soil compaction with organic mulch & Garden et al. 2007 \\
\hline
\end{tabular}

In addition to these general recommendations, there are special landscape situations that merit additional discussion. Many authors have identified the influence of unmanaged ecosystem edges on biodiversity (the "edge effect"). Often, more species are found in these resource-rich transition zones than in the adjacent forests or other natural areas (Zerbe et al. 2003; Crooks et al. 2004; Faggi and Perepelizin 2006; Vallet et al. 2010). In fact, edge environments are key refuges for rare and endangered species, plant and animal alike (Roberts et al. 2007; Vallet et al. 2010).
There are two specific urban environments that naturally contain edges and can be managed to enhance and preserve species biodiversity.

- Golf courses. Though fairways and greens are intensively managed, out-of-bounds areas are similar to the forests found outside courses (Yasuda and Koike 2006). They have a large percentage of edge habitat, a significant amount of deciduous and coniferous tree cover (Hudson and Bird 2009), and include water features. Golf course managers can 
leave out-of-bounds areas unmanaged and increase vegetation surrounding all water bodies (Hudson and Bird 2009), thereby acting as a refuge for flora and fauna (Yasuda and Koike 2006).

- Public and residential gardens and landscapes. Public and private landscapes, dominated by a diverse collection of native and introduced trees and shrubs, are substantial contributors to regional species biodiversity (Yilmaz et al. 2008; Goddard et al. 2010; Molebatsi et al. 2013; Nielsen et al. 2014). They naturally contain a high percentage of edge environments and are usually rich in plants with floral and fruit displays. These characteristics create environments that can be significant refuges for endangered plants and animals (Akinnifesi et al. 2010), and may house more species than either managed or natural areas. Botanically diverse communities are less vulnerable to exotic species invasion (Mandryk and Wein 2006), and if noxious weeds do appear they are likely to be spotted and removed by landscape managers and homeowners before they can establish recalcitrant populations.

\section{CONCLUSIONS}

It is challenging to engage homeowners and landscape managers on the issue of landscape biodiversity, simply because there is no obvious venue for doing so. Certified arborists, Extension specialists, and others should reach out to private property owners with science-based recommendations for attracting and retaining birds, pollinators, and other desirable animal species in their gardens and landscapes. Specific, achievable actions could include:

- reducing open lawn (Marzluff and Ewing 2001; Hudson and Bird 2009) and replacing it with vertically diverse vegetation (Ikin et al. 2013a)

- increasing shrub and tree cover, especially in newer neighborhoods distant from forest edges (Kalinowski et al. 2010; Ikin et al. 2013a)

- $\quad$ selecting both native and noninvasive, introduced trees and shrubs to increase plant diversity (Raupp et al. 2006) and aesthetics
- planting fruit-bearing trees, shrubs, and ground covers for human and animal consumption alike (Campbell and Campbell 2001)

- adding a permanent water feature when feasible

These science-based recommendations for increasing species biodiversity in urban landscapes stand in stark contrast to the list of characteristics used to promote the exclusive use of native plant species. This review demonstrates that nonnative plants will attract and retain beneficial wildlife, including birds, insects, mammals, and reptiles; furthermore, by expanding the acceptable list of landscape trees and shrubs, biological and genetic diversity are enhanced. An additional benefit is that biodiverse landscapes have been positively linked to self-perceived well-being of neighborhood residents. (Luck et al. 2011).

Science-informed decisionmaking must occur in the planning and designing of urban greenspaces as well as in the selection and management of woody species. To paraphrase Sagoff (2005) and Davis et al. (2011), it is time for urban planners to focus on the function of tree species, not on their origin. Urban planners should engage landscape professionals and applied plant scientists in their process so that current, relevant, research-based information can be considered. The message is simple and straightforward: a natives-only tree policy sharply reduces the planting palette and ultimately community biodiversity of urban areas.

Acknowledgments. I am most appreciative of the comments and suggestions made by two anonymous reviewers and the associate editor.

\section{LITERATURE CITED}

Adhikari, Y.P., A. Fischer, and H.S. Fischer. 2012a. Micro-site conditions of epiphytic orchids in a human impact gradient in Kathmandu Valley, Nepal. Journal of Mountain Science 9:331-342.

Adhikari, Y.P., H.S. Fischer, and A. Fischer. 2012b. Host tree utilization by epiphytic orchids in different land-use intensities in Kathmandu Valley, Nepal. Plant Ecology 213:1393-1412.

Akinnifesi, F.K., G.W. Sileshi, O.C. Ajayi, A.I. Akinnifesi, E.G. de Moura, J.F.P. Linhares, and I. Rodrigues. 2010. Biodiversity of the urban homegardens of So Luis City, Northeastern Brazil. Urban Ecosystems 13:129-146.

Andrade-Núñez, M.J., and T.M. Aide. 2010. Effects of habitat and landscape characteristics on medium and large mammal species richness and composition in northern Uruguay. Zoologia 27:909-917. 
Antunes, H.A., L.A. Nunes, J.W.P. daSilva, and L.C. Marchini. 2012. Native bees (Apidae: Meliponina) and their floral resources in a part of a forest located in urban areas. Magistra 24:7-14.

Atchison, K.A., and A.D. Rodewald. 2006. The value of urban forests to wintering birds. Natural Areas Journal 26:280-288.

Basham, R., B. Law, and P. Banks. 2011. Microbats in a 'leafy' urban landscape: Are they persisting, and what factors influence their presence? Austral Ecology 36:663-678.

Blair, R.B. 1996. Land use and avian species diversity along an urban gradient. Ecological Applications 6:506-519.

Blanchon, D., J. Pusateri, M. Galbraith, and S. Thorpe. 2011. Sampling indigenous ground-living beetles in a stand of nonnative tree privet (Ligustrum lucidum) in New Zealand raises new management questions. Ecological Management \& Restoration 12:234-236.

Bonnington, C., K.J. Gaston, and K.L. Evans. 2014. Squirrels in suburbia: Influence of urbanization on the occurrence and distribution of a common exotic mammal. Urban Ecosystems 17:533-546.

Borges Júnior, N.F., G.A. Machado, and L.D. Battirola. 2011. Coprophagous Scarabaeidae (Coleoptera) in fragments of native vegetation (Cerrado) in the urban perimeter of Catalão, Goiás (Brazil). Acta Biológica Paranaense 40:73-85.

Brearley, G., A. Bradley, S. Bell, and C. McAlpine. 2011. Change in habitat resources and structure near urban edges and its influence on the squirrel glider (Petaurus norfolcensis) in southeast Queensland, Australia. Austral Ecology 36:425-432.

Brown, G.W., J.W. Dorrough, and D.S.L. Ramsey. 2011. Landscape and local influences on patterns of reptile occurrence in grazed temperate woodlands of southern Australia. Landscape and Urban Planning 103:277-288.

Brown Júnior, K.S., and A.V.L. Freitas. 2002. Butterfly communities of urban forest fragments in Campinas, São Paulo, Brazil: Structure, instability, environmental correlates, and conservation. Journal of Insect Conservation 6:217-231.

Caldara Jr., V., and Y.L.R. Leite. 2007. Habitat use by small mammals at Parque Estadual da Fonte Grande, Vitória, Espírito Santo, Brazil. Boletim do Museu de Biologia Mello Leitão 21:57-77.

Campbell, R.J., and C.W. Campbell. 2001. Integrating fruit trees and other nonnative plants with native plants in the Southern Florida home garden. Proceedings of the Florida State Horticultural Society 114:1-2.

Catterall, C.P., J.A. Cousin, S. Piper, and G. Johnson. 2010. Longterm dynamics of bird diversity in forest and suburb: Decay, turnover or homogenization? Diversity and Distributions 16:559-570.

Caughlin, T., J.H. Wheeler, J. Jankowski, and J.W. Lichstein. 2012. Urbanized landscapes favored by fig-eating birds increase invasive but not native juvenile strangler fig abundance. Ecology 93:1571-1580.

Chace, J.F., and J.J. Walsh. 2006. Urban effects on native avifauna: A review. Landscape and Urban Planning 74:46-69.

Chen, T.C., B.S. Shieh, and S.H. Liang. 2005. Associations of the community characteristics of woody plants with avian communities in the urban parks of Kaohsiung City. Plant Protection Bulletin (Taipei) 47:229-240.

Chocholoušková, Z., and P. Pyšek. 2003. Changes in composition and structure of urban flora over 120 years: A case study of the city of Plzeň. Flora 198:366-376.
Crooks, K.R., A.V. Suarez, and D.T. Bolger. 2004. Avian assemblages along a gradient of urbanization in a highly fragmented landscape. Biological Conservation 115:451-462.

Daniels, G.D. and J.B. Kirkpatrick. 2012. The influence of landscape context on the distribution of flightless mammals in exurban developments. Landscape and Urban Planning 104:114-123.

Davis, A., C.E. Taylor, and R.E. Major. 2012. Seasonal abundance and habitat use of Australian parrots in an urbanised landscape. Landscape and Urban Planning 106:191-198.

Davis, M.A., M.K. Chew, R.J. Hobbs, A.E. Lugo, J.J. Ewel, G.J. Vermeij, J.H. Brown, M.L. Rosenzweig, et al. 2011. Don't judge species on their origins. Nature (474):153-154.

de Toledo, M.C.B., R.J. Donatelli, and G.T. Batista. 2012. Relation between green spaces and bird community structure in an urban area in Southeast Brazil. Urban Ecosystems 15:111-131.

Delabie, J.H.C., B. Jahyny, I.C. do Nascimento, C.S.F. Mariano, S. Lacau, S. Campiolo, S.M. Philpott, M. Leponce, G. Schroth, and C.A. Harvey. 2007. Contribution of cocoa plantations to the conservation of native ants (Insecta: Hymenoptera: Formicidae) with a special emphasis on the Atlantic Forest fauna of southern Bahia, Brazil. Biodiversity and Conservation 16:2359-2384.

Donnelly, R., and J.M. Marzluff. 2004. Importance of reserve size and landscape context to urban bird conservation. Conservation Biology 18:733-745.

Donnelly, R., and J.M. Marzluff. 2006. Relative importance of habitat quantity, structure, and spatial pattern to birds in urbanizing environments. Urban Ecosystems 9:99-117.

Echevarria, A.L., I.R. Lobo Allende, M.D. Juri, J.M. Chani, J.T. Dowdall, and E. Martín. 2011. Composition, structure and seasonal variation of the bird community in the Botanical Garden of Fundación Miguel Lillo. Acta Zoologica Lilloana 55:123-136.

Eliasaro, S., P.W. Veiga, C.G. Donha, and L. Nogueira. 2009. Inventory of epiphytic macrolichens on trees used in urban arborization in Curitiba, Paraná, Brazil. Biotemas 22(4):1-8.

Engardio, J.P. 2013. Spat over trees amid forest of problems. Accessed 07/14/2014. <www.sfgate.com/opinion/openforum/ article/Spat-over-trees-amid-forest-of-problems-4318571.php>

Environmental Protection Agency (EPA). 2012. Landscaping with Native Plants. Accessed 12/08/2014. <www.epa.gov/greatlakes/ greenacres/nativeplants/factsht.html\#Why\%20Should\%20I>

Faggi, A., and P.V. Perepelizin. 2006. Bird richness along an urbanization gradient in Buenos Aires city. Revista del Museo Argentino de Ciencias Naturales Nueva Serie 8:289-297.

Feldman, R.E., and P.G. Krannitz. 2004. Bird composition of oak ecosystem fragments in an urbanized setting: The influence of adjacent coniferous forest fragments. Ecoscience 11:338-346.

Fernández, I.C., and J.A. Simonetti. 2013. Small mammal assemblages in fragmented shrublands of urban areas of Central Chile. Urban Ecosystems 16:377-387.

Ferracini, C., and A. Alma. 2007. Evaluation of the community of native eulophid parasitoids on Cameraria ohridella Deschka and Dimic in urban areas. Environmental Entomology 36:11471153.

Fetridge, E.D., J.S. Ascher, and G.A. Langellotto. 2008. The bee fauna of residential gardens in a suburb of New York City (Hymenoptera: Apoidea). Annals of the Entomological Society of America 101:1067-1077.

Frankie, G.W., M. Rizzardi, S.B. Vinson, and T.L. Griswold. 2009. Decline in bee diversity and abundance from 1972-2004 on a flowering leguminous tree, Andira inermis in Costa Rica at the 
interface of disturbed dry forest and the urban environment Journal of the Kansas Entomological Society 82:1-20.

Freedman, B., S. Love, and B. O'Neil. 1996. Tree species composition, structure, and carbon storage in stands of urban forest of varying character in Halifax, Nova Scotia. Canadian FieldNaturalist 110:675-682.

Garden, J.G., C.A. McAlpine, and H.P. Possingham. 2010. Multiscaled habitat considerations for conserving urban biodiversity: Native reptiles and small mammals in Brisbane, Australia. Landscape Ecology 25:1013-1028.

Garden, J.G., D.N. Jones, H.P. Possingham, and C.A. McAlpine. 2007. Habitat structure is more important than vegetation composition for local-level management of native terrestrial reptile and small mammal species living in urban remnants: A case study from Brisbane, Australia. Austral Ecology 32:669-685.

Gleditsch, J.M., and T.A. Carlo. 2011. Fruit quantity of invasive shrubs predicts the abundance of common native avian frugivores in central Pennsylvania. Diversity and Distributions 17:244-253.

Goddard, M.A., A.J. Dougill, and T.G. Benton. 2010. Scaling up from gardens: Biodiversity conservation in urban environments. Trends in Ecology and Evolution 25:90-98.

Guthrie, R.J., J.J. Sullivan, and H.L. Buckley. 2008. Patterns of host damage by the cabbage tree monophage Epiphryne verriculata Feld (Lepidoptera: Geometridae) across urban, rural and native forest habitats. New Zealand Entomologist 31:77-88.

Hanley, M.E., A.J. Awbi, and M. Franco. 2014. Going native? Flower use by bumblebees in English urban gardens. Annals of Botany 113:799-806

Hasebe, M., and D.C. Franklin. 2004. Food sources of the Rainbow Lorikeet Trichoglossus haematodus during the early wet season on the urban fringe of Darwin, Northern Australia. Corella 28:68-74.

Helden, A.J., G.C. Stamp, and S.R. Leather. 2012. Urban biodiversity: Comparison of insect assemblages on native and nonnative trees. Urban Ecosystems 15:611-624.

Hennings, L.A., and W.D. Edge. 2003. Riparian bird community structure in Portland, Oregon: Habitat, urbanization, and spatial scale patterns. Condor 105:288-302.

Hitchmough, J. 2011. Exotic plants and plantings in the sustainable, designed urban landscape. Landscape and Urban Planning 100:380-382.

Hodge, S., S.A. Marshall, H. Oliver, J. Berry, J. Marris, and I. Andrew. 2010. A preliminary survey of the insects collected using mushroom baits in native and exotic New Zealand woodlands. New Zealand Entomologist 33:43-54

Hodgkison, S., J.M. Hero, and J. Warnken. 2007. The efficacy of small-scale conservation efforts, as assessed on Australian golf courses. Biological Conservation 135:576-586.

Hudson, M.-A.R., and D.M. Bird. 2009. Recommendations for design and management of golf courses and green spaces based on surveys of breeding bird communities in Montreal. Landscape and Urban Planning 92:335-346.

Ikin, K., E. Knight, D.B. Lindenmayer, J. Fischer, and A.D. Manning. 2013b. The influence of native versus exotic streetscape vegetation on the spatial distribution of birds in suburbs and reserves. Diversity and Distributions 19:294-306.

Ikin, K., R.M. Beaty, D.B. Lindenmayer, E. Knight, J. Fischer, and A.D. Manning. 2013a. Pocket parks in a compact city: How do birds respond to increasing residential density? Landscape Ecology 28:45-56.
Ingram, J. 1999. When cities grow wild-Natural landscaping from an urban planning perspective. Accessed 12/08/2014. <www. wildones.org/whenciti/ingram-32.htm>

Jodice, P.G.R., and S.R. Humphrey. 1992. Activity and diet of an urban-population of Big Cypress fox squirrels. Journal of Wildlife Management 56:685-692.

Johnston, M., S. Nail, and S. James. 2012. 'Natives versus aliens': The relevance of the debate to urban forest management in Britain. pp. 181-191. In: M. Johnston and G. Percival (Eds.). Trees, People, and the Built Environment. Proceedings of the Urban Trees Research Conference, April 13-14, 2011, Birmingham, UK.

Kalinowski, R.S., M.D. Johnson, J.J. Nocera, and M.G. Betts. 2010. Influence of suburban habitat on a wintering bird community in coastal northern California. Condor 112:274-282.

Kath, J., M. Maron, and P.K. Dunn. 2009. Interspecific competition and small bird diversity in an urbanizing landscape. Landscape and Urban Planning 92:72-79.

Kendle, A.D., and J.E. Rose. 2000. The aliens have landed! What are the justifications for 'native only' policies in landscape plantings? Landscape and Urban Planning 47:19-31.

Khera, N., V. Mehta, and B.C. Sabata. 2009. Interrelationship of birds and habitat features in urban greenspaces in Delhi, India. Urban Forestry \& Urban Greening 8:187-196.

Kirkpatrick, J.B. 2004. Vegetation change in an urban grassy woodland 1974-2000. Australian Journal of Botany 52:597-608.

Kirnbauer, M.C., W.A. Kenney, C.J. Churchill, and B.W. Baetz. 2009. A prototype decision support system for sustainable urban tree planting programs. Urban Forestry \& Urban Greening 8:3-19.

Knapp, S., I. Kühn, J. Stolle, and S. Klotz. 2010. Changes in the functional composition of a Central European urban flora over three centuries. Perspectives in Plant Ecology, Evolution and Systematics 12:235-244.

Kulfan, J., E. Kula, P. Zach, K. Dvořačkova, J. Patočka, and B. Kršiak. 2010. Caterpillar assemblages on introduced blue spruce: Differences from native Norway spruce. Allgemeine Forst und Jagdzeitung 181:188-194.

la Sorte, F.A., and W.J. Boecklen. 2005. Temporal turnover of common species in avian assemblages in North America. Journal of Biogeography 32:1151-1160.

Landmann, A. 2006. Dynamics of tree-composition and treedensities in urban greenspaces of Innsbruck, Tyrol: Changes between 1991 and 2004. Berichte des NaturwissenschaftlichMedizinischen Vereins in Innsbruck 93:51-71.

Leveau, C.M., and L.M. Leveau. 2005. Avian community response to urbanization in the Pampean region, Argentina. Ornitologia Neotropical 16:503-510.

Lu, Y.-W., S.-X. Tang, H.-L. Shi, Z.-F. Ding, S.-Q. Bo, and X. He. 2007. Relationship between avian community and habitat in Shanghai urban woodlots in winter. Chinese Journal of Zoology 42:125-130.

Luck, G.W., P. Davidson, D. Boxall, and L. Smallbone. 2011. Relations between urban bird and plant communities and human well-being and connection to nature. Conservation Biology 25:816-826.

Lukas, S.B. 2011. Evaluation of pre-emergence herbicides within a hydromulch cap to determine weed control and safety for two native Hawaiian grasses in a simulated roadside environment. MS Thesis, University of Hawaii. Accessed 07/14/2014. <www. google. $\mathrm{com} / \mathrm{url}$ ? $\mathrm{sa}=\mathrm{t} \& \mathrm{rct}=\mathrm{j} \& \mathrm{q}=\& \mathrm{esrc}=\mathrm{s} \&$ source $=$ web $\& \mathrm{~cd}=4 \&$ ved=0CEIQFjAD\&url=http\%3A\%2F\%2Fwww.ctahr.hawaii.ed 
u\%2FdefrankJ\%2FText\%2520resources\%2FMS_defrense_S Lukas_PP_pdf_03042011\%2FS_Lukas_M_S_Thesis_final._03_31_2011.pdf\&ei=byv0UZaWGaS-igKspIDYAw\&usg= AFQjCNGuJNOunXxSY6qCfrbv5Akcu3zv9w\&sig2=1AYXaC DFPOw4-QKROVjldw\&bvm=bv.49784469,d.cGE\&cad=rja >

Luther, D., J. Hilty, J. Weiss, C. Cornwall, M. Wipf, and G. Ballard. 2008. Assessing the impact of local habitat variables and landscape context on riparian birds in agricultural, urbanized, and native landscapes. Biodiversity and Conservation 17:1923-1935.

MacGregor-Fors, I. 2008. Relation between habitat attributes and bird richness in a western Mexico suburb. Landscape and Urban Planning 84:92-98.

Mandryk, A.M., and R.W. Wein. 2006. Exotic vascular plant invasiveness and forest invasibility in urban boreal forest types. Biological Invasions 8:1651-1662.

Marzluff, J.M., and K. Ewing. 2001. Restoration of fragmented landscapes for the conservation of birds: A general framework and specific recommendations for urbanizing landscapes. Restoration Ecology 9:280-292.

Matter, S.F., J.R. Brzyski, C.J. Harrison, S. Hyams, C. Loo, J. Loomis, H.R. Lubbers, L. Seastrum, T.I. Stamper, A.M. Stein, R. Stokes, and B.S. Wilkerson. 2012. Invading from the garden? A comparison of leaf herbivory for exotic and native plants in natural and ornamental settings. Insect Science 19:677-682.

McIntyre, N.E., and M.E. Hostetler. 2001. Effects of urban land use on pollinator (Hymenoptera: Apoidea) communities in a desert metropolis. Basic and Applied Ecology 2:209-218.

Miller, J.R., J.A. Wiens, N.T. Hobbs, and D.M. Theobald. 2003. Effects of human settlement on bird communities in lowland riparian areas of Colorado (USA). Ecological Applications 13:1041-1059.

Molebatsi, L.Y., S.J. Siebert, S.S. Cilliers, N. Beau, S. Dessein, and E. Robbrecht. 2013. Alien and indigenous plant species diversity of homegardens of a rural settlement in the eastern Kalahari, South Africa. Scripta Botanica Belgica 50:294-303.

Moller, L.A., A.M.T. Skou, and J. Kollmann. 2012. Dispersal limitation at the expanding range margin of an evergreen tree in urban habitats? Urban Forestry \& Urban Greening 11:59-64.

Nagendra, H., and D. Gopal. 2011. Tree diversity, distribution, history and change in urban parks: Studies in Bangalore, India. Urban Ecosystems 14:211-223.

National Park Service (NPS). 2005. Why use native plants? Accessed 12/08/2014. <www.nps.gov/plants/restore/pubs/intronatplant/whyusenatives.htm>

New York City Council. 2010. A Local Law to amend the administrative code of the city of New York in order to increase biodiversity in public landscapes. Accessed 12/08/2014. <http:// legistar.council.nyc.gov/View.ashx? $\mathrm{M}=\mathrm{F} \& \mathrm{ID}=2302354 \&$ GUID $=06679 \mathrm{CDE}-9 \mathrm{~B} 7 \mathrm{~A}-4 \mathrm{FEA}-\mathrm{A} 301-38 \mathrm{DCEBCA} 4 \mathrm{FCF}>$

Nielsen, A.B., M. Annerstedt, S. Maruthaveeranand, C.C. Konijnendijk. 2014. Species richness in urban parks and its drivers: A review of empirical evidence. Urban Ecosystems 17:305-327.

Nuckols, M.S., and E.F. Connor. 1995. Do trees in urban or ornamental plantings receive more damage by insects than trees in natural forests? Ecological Entomology 20:253-260.

Ochoa, J.G., and G.I. Andrade. 2003. The introduced flora to Machu Picchu Sanctuary: An inventory and management priorities for biodiversity conservation. Ecología en Bolivia 38:141-160.

O'Donoghue, A., and C.M. Shackleton. 2013. Current and potential carbon stocks of trees in urban parking lots in towns of the
Eastern Cape, South Africa. Urban Forestry \& Urban Greening 12:443-449.

Oneal, A.S., and J.T. Rotenberry. 2008. Riparian plant composition in an urbanizing landscape in southern California, U.S.A. Landscape Ecology 23:553-567.

Oprea, M., P. Mendes, T.B. Vieira, and A.D. Ditchfield. 2009. Do wooded streets provide connectivity for bats in an urban landscape? Biodiversity and Conservation 18:2361-2371.

Ortega-Alvarez, R., and I. MacGregor-Fors. 2010. What matters most? Relative effect of urban habitat traits and hazards on urban park birds. Ornitologia Neotropical 21:519-533.

Pair, J.C. 1994. Stress tolerant trees for the southern Great Plains. Journal of Arboriculture 20:130-133.

Palomino, D., and L.M. Carrascal. 2005. Birds on novel island environments. A case study with the urban avifauna of Tenerife (Canary Islands). Ecological Research 20:611-617.

Parsons, H., K. French, and R.E. Major. 2004. The influence of remnant bushland on the composition of suburban bird assemblages in Australia. Landscape and Urban Planning 66:43-56.

Pecarevic, M., J. Danoff-Burg, and R.R. Dunn. 2010. Biodiversity on Broadway: Enigmatic diversity of the societies of ants (Formicidae)on the streets of New York City. PLoS One 5(10).

Pennington, D.N., J. Hansel, and R.B. Blair. 2008. The conservation value of urban riparian areas for landbirds during spring migration: Land cover, scale, and vegetation effects. Biological Conservation 141:1235-1248.

Petrova, Y., and A. Irikov. 2012. Influence of vegetation on the avifauna in two urban parks in Plovdiv, Bulgaria. Ecologia Balkanica 4:25-31.

Posa, M.R.C., and N.S. Sodhi. 2006. Effects of anthropogenic land use on forest birds and butterflies in Subic Bay, Philippines. Biological Conservation 129:256-270.

Pozi, M., M. Sorayya, M. Nur Shahidah, and H.C. Ong. 2013. Diversity of plants tended or cultivated in Orang Asli homegardens in Negeri Sembilan, Peninsular Malaysia. Human Ecology 41:325-331.

Pryke, J.S., and M.J. Samways. 2009. Recovery of invertebrate diversity in a rehabilitated city landscape mosaic in the heart of a biodiversity hotspot. Landscape and Urban Planning 93:54-62.

Raju, A.J.S. 2003. The status of pollinators and biodiversity in Asia: An overview. Journal of Palynology 35/36:53-71.

Raupp, M.J., A.B. Cumming, and E.C. Raupp. 2006. Street tree diversity in eastern North America and its potential for tree loss to exotic borers. Arboriculture \& Urban Forestry 32:297-304.

Reichard, S., L. Chalker-Scott, and S. Buchanan. 2001. Interactions among nonnative plants and birds, pp. 179-223. In: J. Marzluff, R.A. Bowman, and R. Donnelly (Eds.). Avian Ecology and Conservation in an Urbanizing World, Kluwer Academic Publishers, Boston, Massachusetts, U.S.

Reichard, S.H., and C.W. Hamilton. 1997. Predicting invasions of woody plants introduced into North America. Conservation Biology 11:193-203.

Reis, E., G.M. López-Iborra, and R.T. Pinheiro. 2012. Changes in bird species richness through different levels of urbanization: Implications for biodiversity conservation and garden design in Central Brazil. Landscape and Urban Planning 107:31-42.

Roberts, D.G., D.J. Ayre, and R.J. Whelan. 2007. Urban plants as genetic reservoirs or threats to the integrity of bushland plant populations. Conservation Biology 21:842-852. 
Ryall, K.L. 2010. Effects of larval host plant species on fecundity of the generalist insect herbivore Ennomos subsignarius (Lepidoptera: Geometridae). Environmental Entomology 39:121-126.

Sagoff, M. 2005. Do non-native species threaten the natural environment? Journal of Agricultural and Environmental Ethics 18:215-236.

Santamour, Jr., F.S. 1978. Developing improved cultivars for urban forests. pp. 491-499. In: G. Hopkins (Ed.). National Urban Forestry Conference Proceedings, National Urban Forestry Conference, Nov 13-16, 1978, Washington, D.C.

Sattler, T., M.K. Obrist, P. Duelli, and M. Moretti. 2011. Urban arthropod communities: Added value or just a blend of surrounding biodiversity? Landscape and Urban Planning 103:347-361.

Schmidt, K.J., H.H. Poppendieck, and K. Jensen. 2014. Effects of urban structure on plant species richness in a large European city. Urban Ecosystems 17:427-444.

Sewell, S.R., and C.P. Catterall. 1998. Bushland modification and styles of urban development: Their effects on birds in south-east Queensland. Wildlife Research 25:1, 41-63.

Shwartz, A., S. Shirley, and S. Kark. 2008. How do habitat variability and management regime shape the spatial heterogeneity of birds within a large Mediterranean urban park? Landscape and Urban Planning 84:219-229.

Smith, R.M., K. Thompson, J.G. Hodgson, P.H. Warren, and K.J. Gaston. 2006. Urban domestic gardens (IX): Composition and richness of the vascular plant flora, and implications for native biodiversity. Biological Conservation 129:312-322.

Smith, V.A. 2013. Lower Makefield breaking ground in mandating native plants. Accessed 07/14/2014. <http://articles.philly. com/2013-07-09/news/40446013_1_native-plants-schuylkilltownship-bringing-nature-home>

Stagoll, K., D.B. Lindenmayer, E. Knight, J. Fischer, and A.D. Manning. 2012. Large trees are keystone structures in urban parks. Conservation Letters 5:115-122.

Standley, L.A. 2003. Flora of Needham, Massachusetts: 100 years of floristic change. Rhodora 105:354-378.

Stewart, G.H., M.E. Ignatieva, C.D. Meurk, and R.D. Earl. 2004. The re-emergence of indigenous forest in an urban environment, Christchurch, New Zealand. Urban Forestry \& Urban Greening 2:149-158.

Strubbe, D., E. Matthysen, and C.H. Graham. 2010. Assessing the potential impact of invasive ring-necked parakeets Psittacula krameri on native nuthatches Sitta europeae in Belgium. Journal of Applied Ecology 47:549-557.

Suarez-Rubio, M., and J.R. Thomlinson. 2009. Landscape and patch-level factors influence bird communities in an urbanized tropical island. Biological Conservation 142:1311-1321.

Tallamy, D.W., and K.J. Shropshire. 2009. Ranking lepidopteran use of native versus introduced plants. Conservation Biology 23:941-947.

Taylor, L., C. Taylor, and A. Davis. 2013. The impact of urbanisation on avian species: The inextricable link between people and birds. Urban Ecosystems 16:481-498.

Tommasi, D., A. Miro, H.A. Higo, and M.L. Winston. 2004. Bee diversity and abundance in an urban setting. Canadian Entomologist 136:851-869.

U.S. Department of Transportation. ND. Roadside use of native plants. Accessed 12/08/2014. <www.environment.fhwa.dot.gov/ ecosystems/vegmgmt_rdsduse2.asp >
Uno, S., J. Cotton, and S.M. Philpott. 2010. Diversity, abundance, and species composition of ants in urban green spaces. Urban Ecosystems 13:425-441.

Vallet, J., V. Beaujouan, J. Pithon, D. Rozé, and H. Daniel. 2010. The effects of urban or rural landscape context and distance from the edge on native woodland plant communities. Biodiversity and Conservation 19:3375-3392.

van Heezik, Y., A. Smyth, and R. Mathieu. 2008. Diversity of native and exotic birds across an urban gradient in a New Zealand city. Landscape and Urban Planning 87:223-232.

van Heezik, Y., K.J.M. Dickinson, S. Porter, and C. Freeman. 2013. Garden size, householder knowledge, and socio-economic status influence plant and bird diversity at the scale of individual gardens. Ecosystems 16:1442-1454.

Village of Riverside, Illinois, U.S. 2010. Landscaping in a landmark village. Accessed 07/14/2014. <www.riverside.il.us/verticalSites/\%7BFF0B0056-4ACF-4890-985A29B8374E9BEE\%7D/uploads/\%7BD808405A-6CDC-42EC813B-0B0470A15866\%7D.PDF>

Whitmore, C., T.E. Crouch, R.H. Slotow, M.A. McGeoch, and M.J. Samways. 2002. Conservation of biodiversity in urban environments: Invertebrates on structurally enhanced road islands. African Entomology 10:113-126.

Wray, J.C., E. Elle, and L.A. Neame. 2014. Floral resources, body size, and surrounding landscape influence bee community assemblages in oak-savannah fragments. Ecological Entomology 39:83-93.

Yasuda, M., and F. Koike. 2006. Do golf courses provide a refuge for flora and fauna in Japanese urban landscapes? Landscape and Urban Planning 75:58-68.

Yates, C.J., S.D. Hopper, and R.H. Taphn. 2005. Native insect flower visitor diversity and feral honeybees on jarrah (Eucalyptus marginata) in Kings Park, an urban bushland remnant. Journal of the Royal Society of Western Australia 88:147-153.

Yilmaz, H., M.A. Irmak, S. Yilmaz, and S. Toy. 2008. Species diversity of four major urban forest types under extreme climate conditions in Erzurum, Turkey. International Journal of Biodiversity Science \& Management 4:154-163.

Yu, T.L., and Y.S. Guo. 2013. Effects of urbanization on bird species richness and community composition. Pakistan Journal of Zoology 45:59-69.

Zerbe, S., U. Maurer, S. Schmitz, and H. Sukopp. 2003. Biodiversity in Berlin and its potential for nature conservation. Landscape and Urban Planning 62:139-148.

Zhu, W.-S., Y.-B. Shen, and X.-Q. Zhang. 2010. Discussion on alien tree species planning in the urban greenspace ecosystem. Journal of Nanjing Forestry University (Natural Sciences Edition) 34:142-148.

Linda Chalker-Scott

Washington State University

Puyallup Research and Extension Center

2606 W. Pioneer

Puyallup, Washington 98371, U.S.

lindacs@wsu.edu 
Résumé. De plus en plus, les regroupements de propriétaires et les municipalités exigent l'utilisation d'une certaine proportion d'arbres et d'arbustes indigènes dans le cadre des nouveaux projets d'aménagement paysager. Les promoteurs de telles pratiques font de nombreuses représentations quant à la supériorité des plantes indigènes sur les espèces introduites, dont leur capacité à accroître la biodiversité des écosystèmes. À l'inverse, les arbres et arbustes non indigènes sont considérés comme nuisant à la biodiversité, principalement parce qu'ils sont apparentés avec certaines espèces envahissantes bien connues. Cette revue de littérature résume les résultats de publications scientifiques portant sur les impacts d'espèces ligneuses indigènes et non indigènes sur la stabilité de paysages urbains en fonction de la biodiversité des plantes, des oiseaux, des insectes, des reptiles et des mammifères qui y sont associés. La prépondérance des études consultées démontre que des paramètres autres que le caractère indigène ou non des espèces, ont une plus grande influence sur la biodiversité de ces groupes. Plutôt que de limiter la sélection des arbres et des arbustes à un choix restreint d'espèces indigènes, une approche davantage concrète et appuyée sur le résultat de recherches est recommandée en vue d'améliorer la biodiversité des paysages urbains.

Zusammenfassung. Hauseigentümervereinigungen un Kommunalverwaltungen haben einen wachsenden Bedarf, einen bestimmten Prozentsatz einheimischer Gehölze auf neuen landschaftlich installierten Flächen zu pflanzen. Diese Mandate zur Verwendung einheimischer Arten machen zahlreiche Ansprüche zur Bevorzugung einheimischer Pflanzen gegenüber eingeführten Arten, einschließlich ihrer Fähigkeit zur Verbesserung der Biodiversität des Ökosystems. Im Kontrast dazu sind nichteinheimische Bäume und Sträucher als schädlich für die Biodiversität gebrandmarkt, in erster Linie weil sie ungünstig verbunden sind mit bekannten invasiven Arten. Dieser Überblick summiert die gegenwärtig publizierte Forschung betreffend des Einflusses auf einheimische und nicht-einheimische Gehölze auf die Stabilität urbaner Landschaftsgestaltung, gemessen an der Biodiversität der assoziierten Pflanzen, Vögel, Insekten, Reptilien und Säugetieren. Die Mehrheit der Studien demonstriert, dass andere Parameter als die Artenherkunft den größten Einfluss auf die Biodiversität dieser Gruppen haben. Statt einer Begrenzung der Baum- und Strauchauswahllisten auf eine enge Gruppe von nativen Arten, wird eine eher praktische, auf den Forschungsergebnissen basierende Handlungsweise zur Verbesserung der Biodiversität urbaner Landschaften vorgeschlagen.

Resumen. Cada vez más, las asociaciones de propietarios y los municipios están requiriendo un cierto porcentaje de árboles y arbustos nativos como parte de cualquier nueva plantación en el paisaje. Esto lleva a numerosos requerimientos en cuanto a la superioridad de las plantas nativas sobre especies introducidas, incluyendo su capacidad para mejorar la biodiversidad de los ecosistemas. Por el contrario, los árboles y arbustos no nativos han sido etiquetados como perjudiciales para la biodiversidad, principalmente porque están impropiamente agrupados con las especies invasoras conocidas. Esta revisión resume la ciencia actual publicada con respecto a los efectos de las especies nativas y no nativas leñosas sobre la estabilidad del paisaje urbano, medido por la biodiversidad de las plantas asociadas, aves, insectos, reptiles y mamíferos. La preponderancia de los estudios demuestra que los distintos parámetros de las especies nativas tienen la mayor influencia en la biodiversidad de estos grupos. En lugar de restringir las listas de selección de árboles y arbustos a una paleta limitada de especies nativas, se sugiere un enfoque más práctico, basado en la ciencia para mejorar de la biodiversidad del paisaje urbano. 